\title{
NEMATICIDAL POTENTIAL OF ESSENTIAL OILS OF Ageratum fastigiatum, Callistemon viminalis AND Schinus terebinthifolius
}

\author{
POTENCIAL NEMATICIDA DE ÓLEOS ESSENCIAIS DE Ageratum fastigiatum, \\ Callistemon viminalis $E$ Schinus terebinthifolius
}

\section{Darlan Ferreira BORGES'; Everaldo Antônio LOPES²; Fernando Rabelo CôRTES; Liliane Evangelista VISÔTTO ${ }^{2}$; Vânia Maria Moreira VALENTE ${ }^{4}$; Matheus de Freitas SOUZA ${ }^{1}$}

1. Doutorando em Fitotecnia, Universidade Federal Rural do Semi-Árido, Mossoró, RN, Brasil, darlan.f.borges@gmail.com; 2. Professor, Doutor, Departamento de Ciências Agrárias, Universidade Federal de Viçosa - UFV, Rio Paranaíba, MG, Brasil; 3. Engenheiro Agrônomo, UFV, Rio Paranaíba, MG, Brasil; 4. Professora, Doutora, Departamento de Ciências Exatas, UFV, Rio Paranaíba, MG, Brasil.

\begin{abstract}
Some essential oils are rich in nematicidal compounds and can be used for the management of plant-parasitic nematodes. Laboratory and field studies aiming to evaluate the efficiency of this compounds are necessary. The objective of this research was to assess the nematicidal potential of essential oils from leaves of Ageratum fastigiatum and Callistemon viminalis, and green and mature fruits of Schinus terebinthifolius on the root-knot nematode Meloidogyne javanica. In laboratory, the essential oil of S. terebinthifolius green fruits reduced hatching by more than $80 \%$ and increased juvenile mortality by $300 \%$ when compared to Tween $20+$ water. In the field, none of the essential oils controlled $M$. javanica in lettuce. In conclusion, the essential oil of $S$. terebinthifolius green fruits reduces the egg hatching and kills $\mathrm{J}_{2}$ of $M$. javanica in laboratory. In an infested field with an average of $555 \mathrm{~J}_{2} / 100 \mathrm{~cm}^{3}$ of soil, the application of the essential oils of S. terebinthifolius, C. viminalis and A. fastigiatum does not control M. javanica in lettuce.
\end{abstract}

KEYWORDS: Alternative control. Meloidogyne javanica. Natural nematicides. Root-knot nematode.

\section{INTRODUCTION}

The management of plant-parasitic nematodes depends on the use of various strategies such as resistant varieties, chemical nematicides, crop rotation, biological control, green manuring, and physical methods (FERRAZ et al., 2010). In an integrated management system, the more options available for farmers, the more efficient and sustainable will be the control of pathogens. Essential oils application may be an additional approach for reducing soil population of plantparasitic nematodes (NTALLI; CABONI, 2012). Nematicidal compounds are found in essential oils of several plants species (ECHEVERRRIGARAY et al., 2010; NTALLI; CABONI, 2012). However, the nematicidal potential of essential oils from many plant species has not been fully explored. For instance, Ageratum fastigiatum (Gardner) King \& Rob, Callistemon viminalis G. Don ex Loud and Schinus terebinthifolius Raddi synthesize various bioactive compounds that may inhibit nematodes.

Ageratum fastigiatum is a plant of the family Asteraceae used in popular medicine due to its cicatrizing and anti-microbial properties. The main compounds produced by this plant are $\beta$ caryophyllene, germacrene D and 1,10-di-epi-(DELVECHIO-VIEIRA et al., 2009). These substances are active against bacteria and insects (TAVARES et al., 2009). Callistemon viminalis (family Myrtaceae) leaves are rich in 1,8-cineol and $\alpha$ pinene. The essential oil of this plant has bactericidal, antioxidant (SALEM et al., 2013) and insecticidal properties (NDOMO et al., 2010). Schinus terebinthifolius (family Anacardiaceae) produces antimicrobial substances such as $\alpha$ felandren, $\beta$-felandren, $\alpha$-terpineol, $\alpha$-pinene, $\beta$ pinene and $\beta$-cymene (BENDAOUD et al., 2010), including fungicidal compounds against species of Alternaria, Botrytis, Colletotrichum and Fusarium (SANTOS et al., 2010).

Due to the multitude of bioactive substances in the essential oils of A. fastigiatum, $C$. viminalis and $S$. terebinthifolius, it is likely that some of them have nematicidal activity. Thus, the objective of this study was to evaluate the effect of the essential oils of these plants on the control of Meloidogyne javanica (Treub) Chitwood under laboratory and field conditions.

\section{MATERIAL AND METHODS}

\section{Plant samples collection and compounds identification}

Leaves of Ageratum fastigiatum, Callistemon viminalis, and green and mature fruits of Schinus terebinthifolius were collected in field areas in Rio Paranaíba and taken to the laboratory 
for oil extraction. Green and mature fruits of $S$. terebinthifolius were used due to their distinct chemical composition (BARBOSA et al., 2007). Approximately $200 \mathrm{~g}$ of fresh leaves and fruits of the plants were ground in a blender and placed in a flask for extraction by steam distillation in a Clevenger system during 1 to 2 hours. After extraction, the oils samples were analyzed by gas chromatography coupled to mass spectrometry (Shimadzu QP2010 Plus). The chromatographic conditions were adjusted according to the procedure described by Barbosa et al. (2007), with a split ratio of $1: 20$ and gas flow of $1.0 \mathrm{~mL} / \mathrm{min}$.

The components were identified by comparing their mass spectra with those available in the NIST spectrographic database and the arithmetic indexes (IA). To calculate the indexes, a mixture of linear alkanes (C9 to C19) was injected into the chromatograph. The IA was calculated for each compound and compared to the values of the literature (ADAMS, 2007), calculated by the equation: IA $(\mathrm{x})=100 \mathrm{Pz}+100[\{\mathrm{RT}(\mathrm{x})-\mathrm{RT}(\mathrm{Pz})\}$ $\{+1)-\mathrm{RT}(\mathrm{Pz})\}]$; where $\mathrm{X}$ is the compound of interest; $\mathrm{Pz}$ is the number of carbon atoms of the hydrocarbon with retention time immediately prior to the retention time of $\mathrm{X}$; RT $(\mathrm{x})$, is the retention time of $\mathrm{X}$; RT $(\mathrm{Pz})$ is the retention time of $\mathrm{Z}$; RT $(\mathrm{Pz}$ $+1)$ is the retention time of the hydrocarbon with retention time immediately after the retention time of $\mathrm{X}$. The relative percentage of each compound was calculated by the ratio of the integral area of their respective peaks to the total area of all constituents of the sample.

\section{Chemical composition of essential oils}

Chromatographic analysis of essential oils showed variation in chemical composition between plants (Table 1). The main compounds of $C$. viminalis and A. fastigiatum were cineol/eucalyptol (74.9\%) and germacrene D (42.1\%), respectively. Sabinene was the major constituent in the oils of green and mature fruits of S. terebinthifolius (35.6 and $38.7 \%)$. High concentration of terpenes was also observed in the oil of $S$. terebinthifolius green fruits, mainly terpinen-4-ol, $\gamma$-terpinene and $\alpha$ terpineol (Table 1).

Table 1. Chemical composition of the essential oils of Callistemon viminalis (CV) leaves, Ageratum fastigiatum (AF) leaves, and Schinus terebinthifolius green (STG) and mature fruits (STM)*.

\begin{tabular}{lllll}
\hline Compound & CV $(\%)$ & AF $(\%)$ & STG $(\%)$ & STM $(\%)$ \\
\hline 3- Carene & - & - & 7.9 & 19.6 \\
$\alpha$ - Pinene & 9.0 & 10.6 & 2.8 & 2.4 \\
$\alpha$-Terpineol & 8.5 & - & 0.9 & 0.3 \\
$\alpha$ - Tujene & 0.1 & - & 1.5 & 1.4 \\
$\alpha$ - Terpinene & - & - & 3.4 & 1.8 \\
$\alpha$ - Bergamotene & - & 1.0 & - & - \\
$\alpha$ - Humulene & - & 9.5 & - & - \\
$\alpha$ - Selinene & - & 2.8 & - & - \\
$\beta$ - Phellandrene & - & - & 2.2 & 2.1 \\
$\beta$ - Elemene & - & 1.5 & - & - \\
$\beta$ - Selinene & - & 3.8 & - & 3.1 \\
$\gamma$ - Terpinene & 0.3 & - & 6.0 & - \\
$\gamma$ - Amorphene & - & 1.3 & 0.2 & - \\
$\gamma$ - Murolene & - & 2.4 & - & 1.1 \\
$\Delta$ - Cadinene & - & 3.8 & 1.6 & - \\
Caryophyllene & - & 13.3 & - & - \\
Cineol/eucalyptol & 74.9 & - & 0.1 & 0.8 \\
Copaene & - & 3.0 & 1.0 & 5.1 \\
E-Caryophyllene & - & - & 5.9 & 3.0 \\
Germacrene D & - & 42.1 & 1.9 & - \\
Limonene & - & 1.5 & - & 3.5 \\
$\beta$ - Mircene & - & - & 1.4 & 1.5 \\
o- Cimene & 2.7 & - & 3.7 & 38.7 \\
Sabinene & 1.5 & - & 35.6 & 1.6 \\
Terpinen-4-ol & - & - & 18.3 & 1.0 \\
Terpinolene & & 0.4 & 1.6 & \\
\hline
\end{tabular}

* Only substances with more than $1 \%$ in the total oil composition of at least one of the plants were listed. 


\section{Nematicidal effect of essential oils in the laboratory}

The experiments were performed in duplicate and a completely randomized design (DIC) with ten replicates. The experimental plot was composed of a well from the 96-well Elisa plate. The effect of essential oils on hatching and mortality of second stage juveniles $\left(\mathrm{J}_{2}\right)$ of $M$. javanica was evaluated in the laboratory. For hatching inhibition tests, ten wells were filled with $100 \mu \mathrm{L}$ of egg suspension containing 30 eggs, $100 \mu \mathrm{L}$ of essential oil and $100 \mu \mathrm{L}$ of $0.3 \%$ Tween 20 aqueous solution. Wells filled with $100 \mu \mathrm{L}$ of egg suspension +200 $\mu \mathrm{L}$ of $0.3 \%$ Tween 20 aqueous solution, and with $100 \mu \mathrm{L}$ of egg suspension $+200 \mu \mathrm{L}$ of water were used as controls.

Regarding the eventual presence of juveniles in the egg suspension, the number of each nematode stage per well was assessed immediately after the beginning of the experiment, with the aid of an inverted objective optical microscope. After, the plates were sealed with plastic film and maintained in an incubator at $27^{\circ} \mathrm{C}$. The assay was assessed every $24 \mathrm{~h}$ for five days.

Similar procedures were carried out to evaluate nematicidal/nematostatic effect of essential oils on juveniles. Thirty freshly hatched juveniles were used in each well. The number of mobiles and immobile juveniles was counted every 24 hours. At the end of the fifth day, the juveniles were transferred to a 324-mesh sieve, washed with distilled water, and placed back into the wells filled with distilled water. The plates remained at $27{ }^{\circ} \mathrm{C}$ for $24 \mathrm{~h}$, when the number of dead and alive juveniles was recorded.

\section{Nematicidal effect of essential oils in the field}

The field experiment was carried out from March to May 2016. Raised beds (1.2 wide and 0.2 high) were prepared and the soil was irrigated to the field capacity. Fertilizers were applied according to the lettuce requirement. Simple soil samples were taken to form a composite sample, and to quantify the initial population of nematodes. The nematodes were extracted from the soil (JENKINS, 1964) and quantified using light microscopy. The initial population was $554 \mathrm{~J}_{2} / 100 \mathrm{~cm}^{3}$ of soil.

The plots (1.5 length and $1.2 \mathrm{~m}$ wide) were covered with a black tarp to prevent oil losses by volatilization. Plots were individually covered, and the edges of the tarps were buried approximately 15 $\mathrm{cm}$ deep. Each plot consisted of three planting lines spaced $0.3 \mathrm{~m}$ apart, with four plants in each row spaced $0.3 \mathrm{~m}$ apart. The useful plot area was composed by two central plants of the middle line.
For application, $2 \mathrm{~mL}$ of essential oil were emulsified with Tween 20 and $296 \mathrm{~mL}$ of water. Twenty-five $\mathrm{mL}$ of this emulsion was applied at the center of each plot using a syringe. After the application, the holes on the tarps were immediately sealed with adhesive tape to prevent losses by volatilization. Twenty-five $\mathrm{mL}$ of water or water + Tween 20 were applied as controls. The soil cover was removed seven days after the application of the oils. Three days after removing plastic cover, lettuce seedlings cv. Milena (25 days old) were transplanted at the plots. The six treatments were randomly distributed in five blocks.

At 40 days after transplanting, the plants were harvested, and soil samples were removed for evaluation of the final nematode population. Total mass of plants, shoot, and fresh roots were recorded using a digital scale. The nematode eggs were extracted (HUSSEY; BARKER, 1973) and counted using a light microscope. The number of root galls was evaluated by direct counting with naked eye. The number of $\mathbf{J}_{2}$ per plot was evaluated as previously described. The final population was calculated as the sum of the number of juveniles, eggs, and root galls. The reproduction factor was calculated as $\mathrm{RF}=\mathrm{Pf} / \mathrm{Pi}$, where $\mathrm{Pf}$ is the final population and $\mathrm{Pi}$ is the initial $\mathrm{J} 2$ population in the soil (OOSTENBRINK, 1966). The data were submitted to analysis of variance by the $\mathrm{F}$ test ( $\mathrm{p}$ $<0.05)$ and the means were compared by the Tukey test $(\mathrm{p}<0.05)$.

\section{RESULTS AND DISCUSSION}

\section{Nematicidal effect of essential oils in the laboratory}

The essential oil of $S$. terebinthifolius green fruits decreased $M$. javanica hatching from 82 to $86 \%$ and increased juvenile mortality by $300 \%$ when compared to the mixed Tween 20 and water, used as emulsifiers (Table 2). However, essential oil of mature fruits did not inhibit hatching compared to the emulsifying mix. Based on the chemical composition of $S$. terebinthifolius oils, the major difference was the highest concentration of terpenes in green fruits, especially terpinen-4-ol, $\alpha$-terpinene, $\gamma$-terpinene and $\alpha$-terpineol (Table 1).

The nematicidal effect of the essential oil of S. terebinthifolius green fruits may be due to its highest concentration of monoterpenoids, especially terpinen-4-ol and $\alpha$ - terpineol (BAKKALI et al., 2008; ECHEVERRIGARAY et al., 2010). The essential oils of $C$. viminalis and $A$. fastigiatum are rich in eucalyptol (1,8-cineol) and germacrene $\mathrm{D}$, 
respectively, but they are poor in terpinen-4-ol is low (Table 1).

Table 2. Effect of essential oils of Callistemon viminalis leaves (CV), Ageratum fastigiatum leaves (AF), Schinus terebinthifolius green (STG) and mature (STM) fruits on hatching and mortality Meloidogyne javanica second-stage juveniles $\left(\mathrm{J}_{2}\right)$ in laboratory.

\begin{tabular}{lcccc}
\hline \multirow{2}{*}{ Treatments } & \multicolumn{2}{c}{ Hatching $(\%)$} & \multicolumn{2}{c}{ Mortality (\%) } \\
\cline { 2 - 5 } & Exp. 1 & Exp. 2 & Exp. 1 & Exp. 2 \\
\hline CV & $18.03 \mathrm{c}$ & $14.39 \mathrm{c}$ & $16.62 \mathrm{~b}$ & $15.38 \mathrm{c}$ \\
AF & $18.58 \mathrm{c}$ & $25.38 \mathrm{ab}$ & $15.82 \mathrm{~b}$ & $16.87 \mathrm{bc}$ \\
STG & $2.89 \mathrm{~d}$ & $3.51 \mathrm{~d}$ & $26.04 \mathrm{a}$ & $21.22 \mathrm{a}$ \\
STM & $26.45 \mathrm{~b}$ & $22.76 \mathrm{ab}$ & $19.38 \mathrm{~b}$ & $19.70 \mathrm{ab}$ \\
Tween 20+water & $21.35 \mathrm{c}$ & $19.93 \mathrm{bc}$ & $3.35 \mathrm{c}$ & $6.58 \mathrm{~d}$ \\
Water & $33.29 \mathrm{a}$ & $28.25 \mathrm{a}$ & $1.24 \mathrm{c}$ & $3.02 \mathrm{e}$ \\
\hline \multicolumn{1}{c}{ CV $(\%)$} & 18.23 & 28.60 & 31.82 & 19.00 \\
\hline
\end{tabular}

Means followed by the same letter in the column do not differ from each other by the Tukey test $(\mathrm{p}<0.05)$. The oils were emulsified with $0.3 \%$ Tween 20 aqueous solution.

The anti-nematode activity of terpenoids depends on their reactive groups and chemical structure (ECHEVERRIGARAY et al., 2010). In general, monoterpenoids with hydroxyls or carbonyl groups, including terpinen-4-ol and $\alpha$ - terpineol, have a stronger nematicidal activity than other terpenoids (ECHEVERRIGARAY et al., 2010). The lipophilic properties of natural terpenoids are potentially related to their detrimental effect on cell membranes of numerous living organisms, including plant-parasitic nematodes (ECHEVERRIGARAY et al., 2010; NTALLI et al., 2011).

\section{Nematicidal effect of essential oils in the field}

The application of $C$. viminalis essential oil increased lettuce biomass by $46.93 \%$ in comparison to the emulsifier $0.3 \%$ Tween 20 solution (Table 3). None of the essential oils reduced the final population and the reproduction factor of $M$. javanica in the field (Table 3). Reproduction factor ranged from 1.8 to 2.91 (Table 3 ).

Table 3. Effect of essential oils of Callistemon viminalis (CV) leaves, A. fastigiatum (AF) leaves and Schinus terebinthifolius green (STG) and mature (STM) fruits on the lettuce biomass and on the reproduction factor of Meloidogyne javanica in a naturally infested field.

\begin{tabular}{lcccc}
\hline Treatment & Biomass* $(\mathrm{g})$ & $\mathrm{Pi}$ & $\mathrm{Pf}$ & Rf \\
\hline CV & $100.56 \mathrm{a}$ & $580.80 \mathrm{~b}$ & $1,041.7 \mathrm{ab}$ & $1.81 \mathrm{~b}$ \\
AF & $73.81 \mathrm{bc}$ & $730.20 \mathrm{a}$ & $1,494.5 \mathrm{a}$ & $2.06 \mathrm{~b}$ \\
STG & $70.20 \mathrm{bc}$ & $550.80 \mathrm{bc}$ & $1,055.6 \mathrm{ab}$ & $1.91 \mathrm{~b}$ \\
STM & $81.60 \mathrm{bc}$ & $520.40 \mathrm{bc}$ & $1,525.6 \mathrm{a}$ & $2.91 \mathrm{a}$ \\
Tween $20+$ water & $68.44 \mathrm{c}$ & $495.80 \mathrm{bc}$ & $1,180.4 \mathrm{ab}$ & $2.39 \mathrm{ab}$ \\
Water & $85.73 \mathrm{ab}$ & $451.60 \mathrm{c}$ & $943 \mathrm{~b}$ & $2.09 \mathrm{~b}$ \\
\hline CV $(\%)$ & 10.34 & 9.29 & 20.67 & 18.25 \\
\hline
\end{tabular}

Means followed by the same letter in the column do not differ from each other by the Tukey test (p < 0.05). *Fresh plants. Pi: Initial population of second-stage juveniles $\left(\mathrm{J}_{2}\right)$ in $100-\mathrm{cm}^{3}$ of soil. Average $\mathrm{Pi}=555 \mathrm{~J}_{2} / 100 \mathrm{~cm}^{3}$ of soil. Pf: Final population; the sum of the average number of galls and eggs per plant and the number of $\mathrm{J}_{2} / 100 \mathrm{~cm}^{3}$ of soil. Rf: Reproduction factor $=\mathrm{Pf} / \mathrm{Pi}$. The oils were emulsified with $0.3 \%$ Tween 20 aqueous solution.

We covered the soil surface of the experimental plots to prevent losses of nematicidal volatile compounds of the essential oils, mainly monoterpenoids from S. terebinthifolius green fruits. Although is likely that plastic covering reduced losses of volatile compounds, the applied amount of essential oil may not have been enough to suppress $M$. javanica, especially when the initial nematode density is as high as an average of $555 \mathrm{~J}_{2} / 100 \mathrm{~cm}^{3}$ (Table 3). In general, initial densities higher than $100 \mathrm{~J}_{2} / 100 \mathrm{~cm}^{3}$ of soil are limiting to susceptible crops to the root-knot nematode, including lettuce, 
tomato, potato and carrot (GRECO; DI VITO, 2009).

Additional management strategies should be adopted to reduce the initial nematode population in highly infested areas, such as crop rotation, use of antagonistic plants, physical, chemical and biological control (FERRAZ et al., 2010). The use of formulations with higher concentration of essential oils, especially those that allow the slow release of the active compounds, can increase the efficiency of this management strategy (NTALLI; CABONI, 2012; BORGES et al., 2018).

Some of the tested compounds in this work demonstrated efficiency for handling under laboratory conditions, thus formulations that ensure the best performance of these compounds under field conditions may be the output to make feasible the use of some essential oils with nematicidal potential under field conditions. Further studies using slow-release formulations containing essential oils of $C$. viminalis, A. fastigiatum and $S$. terebinthifolius in fields with lower nematode densities are needed.

\section{CONCLUSIONS}

The oil of green fruit of $S$. terebinthifolius reduces the hatching and kills $\mathrm{J}_{2}$ of $M$. javanica in laboratory.

In an infested field with an average of 555 $\mathrm{J}_{2} / 100 \mathrm{~cm}^{3}$ of soil, the application of the essential oils of $S$. terebinthifolius, $C$. viminalis and $A$. fastigiatum does not control M. javanica in lettuce.

\section{ACKNOWLEDGEMENTS}

To "Conselho Nacional de Desenvolvimento Científico e Tecnológico (CNPq)" for the financial support (Proc. 474456 / 2013-7) and the Research Productivity grant (Proc. 304663 / 2014-0).

RESUMO: Alguns óleos essenciais são ricos em compostos nematicidas e poderiam ser usados no manejo de fitonematoides. Estudos laboratoriais e de campo que visam avaliar a eficiência desses compostos são necessários. O objetivo desta pesquisa foi avaliar o potencial nematicida de óleos essenciais de folhas de Ageratum fastigiatum e Callistemon viminalis e frutos verdes e maduros de Schinus terebinthifolius sobre o nematoide de galhas Meloidogyne javanica. Em laboratório, o óleo essencial de frutos verdes de S. terebinthifolius reduziu mais de $80 \%$ a eclosão e aumentou em 300\% a mortalidade de juvenis em comparação com Tween 20 + água. No campo, nenhum óleo essencial controlou $M$. javanica em alface. Em conclusão, o óleo de frutos verdes de $S$. terebinthifolius reduz a eclosão e mata $\mathbf{J}_{2}$ de M. javanica em laboratório. Em campo com infestação média de $555 \mathrm{~J}_{2} / 100 \mathrm{~cm}^{3}$ de solo, a aplicação dos óleos essenciais de S. terebinthifolius, $C$. viminalis e A. fastigiatum não controla $M$. javanica em alface.

PALAVRAS-CHAVE: Controle alternativo. Meloidogyne javanica. Nematicidas naturais. Nematoide de galhas.

\section{REFERENCES}

ADAMS, R. P. Identification of essential oil components by gas chromatography/mass spectrometry. Illinois USA: Allured Publishing Corporation, Carol Stream, 2007. 804 p.

BAKKALI, F.; AVERBECK, S.; AVERBECK, D.; IDAOMAR, M. Biological effects of essential oils - A review. Food and Chemical Toxicology, Amsterdam, v. 46, n. 4, p. 446-475, 2008.

http://dx.doi.org/10.1016/j.fct.2007.09.106

BARBOSA, L. C. A.; DEMUNER, A. J.; CLEMENTE, A. D.; PAULA, V. F. D.; ISMAIL, F. Seasonal variation in the composition of volatile oils from Schinus terebinthifolius Raddi. Química Nova, São Paulo, v. 30, n. 8, p. 1959-1965, 2007. http://dx.doi.org/10.1590/S0100-40422007000800030

BENDAOUD, H.; ROMDHANE, M; SOUCHARD, J. P.; CAZAUX, S.; BOUAJILA, J. Chemical composition and anticancer and antioxidant activities of Schinus molle L. and Schinus terebinthifolius Raddi berries essential oils. Journal of Food Science, Chicago, v. 75, n. 6, p. 466-472, 2010.

http://dx.doi.org/10.1111/j.1750-3841.2010.01711.x 
BORGES, D. F.; LOPES, E. A.; MORAES, A. R. F.; SOARES, M. S.; VISÔTTO, L. E.; OLIVEIRA, C. R.; VALENTE, V. M. M. Formulation of botanicals for the control plant-pathogens: A review. Crop Protection, Amsterdam, v. 110, p. 135-140, 2018. https://doi.org/10.1016/j.cropro.2018.04.003

DEL-VECHIO-VIEIRA, G.; SOUSA, O. V.; YAMAMOTO, C. H.; KAPLAN, M. A. Chemical composition and antimicrobial activity of the essential oils of Ageratum fastigiatum (Asteraceae). Records of Natural Products, Gebze-Kocaeli, v. 3, n. 1, p. 52-57, 2009.

ECHEVERRIGARAY, S.; ZACARIA, J.; BELTRÃO, R. Nematicidal activity of monoterpenoids against the root-knot nematode Meloidogyne incognita. Phytopathology, St. Paul, v. 100, n. 2, p. 199-203, 2010. http://dx.doi.org/10.1094/PHYTO-100-2-0199

FERRAZ, S.; FREITAS, L. D.; LOPES, E. A.; DIAS-ARIEIRA, C. R. Manejo sustentável de fitonematoides. Viçosa: Editora UFV, 2010. 306 p.

GRECO, N.; DI VITO, M. Population dynamics and damage levels. In: PERRY, R.N.; MOENS, M.; SARR, J.L. Root-Knot Nematodes. CABI, Wallingford, UK, 2009. Cap.11, p. 246-274.

HUSSEY, R. S.; BARKER, K. R. Comparison of methods of collecting inocula of Meloidogyne spp., including a new technique. Plant Disease Reporter, St. Paul, v. 57, n. 12, p. 1025-1028, 1973.

JENKINS, W. R. A rapid centrifugal-flotation technique for separating nematodes from soil. Plant Disease Reporter, St. Paul, v. 48, n. 9, p. 692, 1964.

LOPES, E. A.; FERRAZ, S.; FREITAS, L. G.; FERREIRA, P. A.; AMORA, D. X. Efeito dos extratos aquosos de mucuna preta e de manjericão sobre Meloidogyne incognita e M. javanica. Nematologia Brasileira, São Paulo, v. 29, n. 1, p. 67-74, 2005.

NDOMO, A. F.; TAPONDJOU, L. A.; NGAMO, L. T.; HANCE, T. Insecticidal activities of essential oil of Callistemon viminalis applied as fumigant and powder against two bruchids. Journal of Applied Entomology, Hoboken, v. 134, n. 4, p. 333-341, http://dx.doi.org/2010. 10.1111/j.1439-0418.2009.01475.x

NTALLI, N. G.; CABONI, P. Botanical nematicides: a review. Journal of Agricultural and Food Chemistry, Washington, v. 60, n. 40, p. 9929-9940, 2012. http://dx.doi.org/10.1021/jf303107j

NTALLI, N. G.; FERRARI, F.; GIANNAKOU, I.; MENKISSOGLU-SPIROUDI, U. Synergistic and antagonistic interactions of terpenes against Meloidogyne incognita and the nematicidal activity of essential oils from seven plants indigenous to Greece. Pest Management Science, New York, v. 67, p. 341-351, 2011. http://dx.doi.org/10.1002/ps.2070

OOSTENBRINK, M. Major characteristics of the relation between nematodes and plants. Mendelingen Landbouwhogeschool Wageningen, Wageningen, v. 66, p. 1- 46, 1966.

SALEM, M. Z.; ALI, H. M.; EL-SHANHOREY, N. A.; ABDEL-MEGEED, A. Evaluation of extracts and essential oil from Callistemon viminalis leaves: Antibacterial and antioxidant activities, total phenolic and flavonoid contents. Asian Pacific Journal of Tropical Medicine, Hainan, v. 6, n. 10, p. 785-791, 2013. http://dx.doi.org/10.1016/S1995-7645(13)60139-X

SANTOS, A. C. A.; ROSSATO, M.; SERAFINI, L. A.; BUENO, M.; CRIPPA, L. B.; SARTORI, V. C.; DELLACASSA, E.; MOYNA, P. Efeito fungicida dos óleos essenciais de Schinus molle L. e Schinus terebinthifolius Raddi, Anacardiaceae, do Rio Grande do Sul. Revista Brasileira de Farmacognosia, Curitiba, v. 20, n. 2, p. 154-159, 2010. 
TAVARES, W. S.; CRUZ, I.; PETACCI, F.; ASSIS JÚNIOR, S. L.; FREITAS, S. S.; ZANUNCIO, J. C.; SERRÃO, J. E. Potential use of Asteraceae extracts to control Spodoptera frugiperda (Lepidoptera: Noctuidae) and selectivity to their parasitoids Trichogramma pretiosum (Hymenoptera: Trichogrammatidae) and Telenomus remus (Hymenoptera: Scelionidae). Industrial Crops and Products, Philadelphia, v. 30, n. 3, p. 384-388, 2009. http://dx.doi.org/10.1016/j.indcrop.2009.07.007 